\title{
INTRODUCTION: THE ARCHITECTONICS OF ANSWERABILITY
}

There is a story to the effect that Queen Victoria was so delighted by Alice in Wonderland that she left a standing order for the author's next book. The following year (I866) she was not at all amused when she received a formidably technical treatise on logic called Condensation of Determinants by Charles Lutwidge Dodgson, which was, of course, Lewis Carroll's real name.' Anglophone readers of Bakhtin may experience something like Queen Victoria's chagrin when they start working their way through the works in this third volume of Bakhtin translations to appear in the University of Texas Press Slavic Series. ${ }^{2}$ The essays assembled here are all very early and differ in a number of ways from Bakhtin's previously published work. Readers will probably first suspect that they are encountering a "new Bakhtin" in the style of these essays. One reason why Bakhtin has so quickly become popular with so many (and varied) readers is that they have found him easy to read, at least by comparison with other theorists now competing for attention. These texts, by contrast, are extremely difficult and make demands on the reader's erudition, powers of synthesis, and sheer patience not encountered in the books that have defined Bakhtin's achievement in the recent past. In addition, many of their terms and concepts are currently unfashionable. At a time when "the author" has long been presumed dead, and when the words "hero" and "aesthetics" have a certain anachronistic ring to them, a long monograph called "Author and Hero in Aesthetic Activity" will require of its readers an extra degree of imagination and sympathy. Obviously, we believe the extra effort will be well repaid, first of all because these texts 
make possible a deeper understanding of Bakhtin's previously published books.

A major topic in these works is "architectonics," a term that in Bakhtin's thought is constantly taking on new meaning in the different contexts in which it is invoked. But at this preliminary state, architectonics can be understood as concerned with questions of building, of the way something is put together. Architectonics provides the ground for Bakhtin's discussion of two related problems in these essays. The first is how relations between living subjects get ordered into categories of "I" and "another." The second is how authors forge the kind of tentative wholeness we call a text out of the relation they articulate with their heroes. More particularly, architectonics also provides a conceptual armature for his later, more partial readings of specific works and authors, in all of which, in one way or another, the relation of parts to wholes figures prominently. In his disputations with other schools /such as Formalism in the early text included here called "The Problem of Content, Material, and Form in Verbal Art," or, in his last years, when indicating weaknesses in Structuralism/, Bakhtin's argument usually includes the charge that his opponents have not completely theorized their position. He criticizes their lack of philosophical thoroughness largely because they fail to provide their particular pronouncements with an overarching conceptual framework of the kind he had provided in these early works for his own subsequent studies of more highly particularized subjects.

Aesthetics, another major topic of these essays, is treated by Bakhtin as a subset of architectonics: architectonics is the general study of how entities relate to each other, whereas aesthetics concerns itself with the problem of consummation, or how parts are shaped into wholes. Wholeness, or consummation, is always to be understood here as a relative term: in Bakhtin, consummation is almost literally in the eye of the beholder. As will become clearer in what follows, wholeness is a kind of fiction that can be created only from a particular point of view. When invoking the term, one should always keep in mind the twin questions: "consummatedby (for) whom?" and "consummated-when?" Consummated wholes may be of one kind or another, but for Bakhtin, who sought to make loopholes into (almost) metaphysical categories, their wholeness can never be absolute. A major irony, amidst a host of other ironies, is that these texts that wrestle with the problem of 
wholeness are themselves incomplete, raising first of all the problems of their genre. What shall we call these fragments? In what follows I shall refer to them as "essays," because-although they are parts of larger texts, they are not as they now stand full-fledged works. They also have the quality of essays because they are clearly attempts to test out, to contest, to try the propositions they engage.

How to shape heterogeneous parts into a (positionally) consummated whole is a problem Bakhtin seeks to resolve at various levels. One of the more important of these is the kind of whole we consummate when we shape the life of another person into a biography. It may, then, help to place these essays in Bakhtin's own oeuvre if we remember the kind of biography it has become conventional to consummate for Bakhtin himself. Bakhtin's mature career is usually divided into the following chapters. In the early Nevel'/Vitebsk period (I9I9-I924), he wrote a number of philosophical works, chiefly in the area of a broadly conceived notion of aesthetics. This was followed by a Leningrad period (1924r 929) during which he completed manuscripts-some of which, published under the names of his friends, continue to arouse dispute over his authorship-devoted to a wide range of particular figures and topics. After his arrest in 1929 there is a long period of exile and a return to the provinces (1930s to 1960s) during which he worked on the history and theory of the novel. Bakhtin's late period (roughly from the mid-I 960s to his death in 1975) included the appearance of many of his formerly unpublished manuscripts, a move to Moscow, and work on several of the philosophical topics that had preoccupied him in his youth. He returned, in other words, to the problems he first laid out for himself in the essays included here, all written in the five years between 1919 and 1924 .

In the spring of 1918 , Bakhtin finished his studies in classical philology at the University of Petersburg. Like many others, he sought relief from the chaos that followed in the immediate wake of the revolution by going into country districts where food and fuel were more abundant. He ended up in the western provinces, where he quickly became a member of a small group of intellectuals who feverishly threw themselves into the debates, lectures, demonstrations, and manifesto writing that characterized life at that extraordinary time. It was in this atmosphere of immense intellectual and political intensity that Bakhtin sought to think through for himself some of the problems then of most concern to 
philosophers, such as (to name only a few) the status of the knowing subject, the relation of art to lived experience, the existence of other persons, and the complexities of responsibility in the area of discourse as well as in the area of ethics.

Bakhtin had already immersed himself in philosophy from a very early age, particularly in ancient Greek, Hellenistic, and modern European philosophy. Thanks to his unusually well-educated German governess, he not only grew up speaking German at home, but even began his reading of the Greek classics in German translation. He read the German systematic philosophers, as well as Buber and Kierkegaard, while still a gymnasium student in Vilnius and Odessa. At the university, he trained as a scholar in the Greek and Latin classics as they were taught in the old German philological tradition, in which the studies of literature and language were inextricably bound to each other. But Tadeusz Zielinski, his eminent professor of classics, emphasized in addition the need to know the whole spectrum of classical civilization, including philosophy. After leaving the university, Bakhtin moved to the west Russian town of Nevel', where he immediately fell in with a group of young people passionately devoted to study and disputation of the latest developments in philosophy. In Nevel' and later in Vitebsk, Bakhtin was surrounded by intense philosophical debates. These took place not only in his study circle, but in public forums organized by the local party committee. Thus, while Bakhtin was still unusually young to be addressing the subjects in these essays-he wrote them all between the ages of twentythree and twenty-eight-he had already been saturated in philosophical thinking for some time. The particular school that dominated the academic study of philosophy in Europe during these years and was of great importance to the young Bakhtin was NeoKantianism. Since these essays draw heavily on Neo-Kantian concepts and terminology, a few words about Neo-Kantianism may be in order. ${ }^{3}$

By I 9 I 8 , Neo-Kantianism had been the dominant school of philosophy in Germany for almost fifty years. From roughly the I 870 s until the 1920s, most professors of philosophy in Germany defined themselves by taking a position vis-à-vis Kant. During this period, most Russians considered Germany to be the home of true philosophical thought. Chairs at the leading universities not only in Germany but in Russia as well were held by Neo-Kantians of one kind or another. They were particularly well entrenched at 
Petersburg University during the years when Bakhtin was a student there. ${ }^{4}$ Although Neo-Kantianism was a widespread phenomenon that included several philosophies that were highly varied in their concerns, the one feature of Kant's thought they all had to confront was the master's formulation of the mind's relation to the world, the innovation that was at the heart of his "Copernican revolution." In Kant's view, his predecessors had either, like Leibniz, overemphasized the role of intellectualized appearances, thus diminishing the role of the world outside the mind, or, like Locke, had gone too far in the opposite direction by sensualizing concepts, making the mind merely a receptor of information provided by sensations from the world. Kant's breakthrough was to insist on the necessary interaction-the dialogue as Bakhtin would come to interpret it-between mind and world. Kant argued that what we call thought is really a synthesis of two forms of knowledge, sensibility and understanding. Sensibility may be taken roughly to mean what empiricists such as Locke or Hume assumed to be the sole basis of knowledge, the realm of physical sensation. And Kant's use of understanding is roughly what rationalists, such as Leibniz, assumed to be the sole basis of knowledge, the realm of concepts in the mind. The ability to think, which Kant assumed to mean the ability to make judgments, requires both forms of knowledge, which he triumphantly brought together in his "transcendental synthesis": a priori concepts, he argucd, do exist in the mind, but they can be used actively to organize sensations from the world outside the mind. The world, the realm of things-in-themselves, really exists, but so does the mind, the realm of concepts. Thought is the give and take between the two.

Those who came after Kant interpreted this synthesis in various ways. The particular Neo-Kantianism in which the young Bakhtin steeped himself was founded in the late nineteenth century at Marburg University by Hermann Cohen. ${ }^{5}$ Cohen radically revised the mind/world relation as Kant had defined it. He emphasized the trancendental aspects of Kant's synthesis, pursuing the quest for a oneness so immaculate that it made him a hero to other seekers after purity, such as the young Pasternak, who in I 9 I 2 traveled to Marburg to sit at the feet of the great man. It was the same lust for unity in Cohen that inspired another Russian, Lenin, to attack him as a particularly militant idealist. ${ }^{6}$ What attracted Pasternak and repelled Lenin was Cohen's opposition to 
the potential dualism in Kant's account of how internal thought relates to the external world. Cohen had a remarkably precise mind, and his philosophy is a model of systematicness that sought to unify all operations of consciousness. Roughly stated, his method for doing so was to abandon Kant's thing-in-itself in order to declare a "logic of pure knowing" in which there is only a realm of concepts: ${ }^{7}$ the world exists as the subject of thought, and the subject of thought, no matter how material it might appear, is still always a subject that is thought.

Bakhtin's connection with the Marburg school was relatively direct, in that his closest friend during the years he was in Nevel' and Vitebsk was Matvei Isaevich Kagan, who returned to Nevel' from Germany almost simultaneously with Bakhtin's arrival there from Petrograd. Kagan was a man of remarkable intellect who commanded the respect of all who came into contact with him. Originally fleeing to Germany to escape persecution as a Jew and to pursue study in mathematics and physics, he had taken up the study of philosophy with Cohen in Marburg. Kagan's move from the exact sciences to philosophy was not unusual in the years just before World War I, when scientists such as Hermann von Helmholtz sought to reinterpret Kant through the logic of mathematics and the workings of the human nervous system, or when physicists such as Ernst Mach applied what they had learned about the nature of matter and energy in the laboratory to the great questions of metaphysics. The Marburg school was the version of academic Neo-Kantianism most concerned with uniting new discoveries in the sciences with the study of philosophy, so Kagan felt quite at home in the old German university on the heights above the river Lahn. But Kagan's budding career as a philosopher in Germany was interrupted by the outbreak of the war in 1914 ; during the next four years, he was held as an enemy alien (although Cohen himself had intervened on his behalf). He was released for repatriation to Russia only after the signing of the treaty of Brest Litovsk in 1918. The enthusiasm of Bakhtin and his friends for German philosophy was given new depth and impetus by Kagan's return.

Two general aspects of Marburg Neo-Kantianism that played an important role in the composition of these essays should be emphasized. The first of these is the Neo-Kantian desire to relate traditional problems in philosophy to the great new discoveries about the world and nature being made in the exact and biological sci- 
ences on the cusp of the nineteenth and twentieth centuries. Bakhtin himself was intensely interested in science, particularly the new physics of Max Planck, Albert Einstein, and Niels Bohr, and current developments in physiology, particularly the study of the central nervous system, an area in which Petersburg was one of the world centers. His closest friends were either lapsed mathematicians such as Kagan or, in later years, scientists such as the biologist (and historian of science) Ivan Kanaev. This aspect of his activity will perhaps explain the attention paid to questions of perception and materiality in these essays. They share in the general effort of thinkers in the early years of the twentieth century to come to grips with the new problems raised by theoretical physics and the new physiology for anyone concerned with the traditional issues of how mind relates to body, and how physical matter relates to such apparently immaterial entities as relations between things. There is a certain lack of clarity about these issues in Bakhtin's philosophy, deriving in some measure from ambiguities inherent in the treatment of the same topics in contemporary science. At a time when Einstein was taking the first steps toward redefining what had appeared to be static physical objects as forms of volatile energy, it is perhaps not surprising that matter-while still being a basic category-did not have the kind of certainty that was unproblematically assumed in traditional (binary) distinctions between matter and mind, or body and soul.

A second aspect of the Marburg school's activity that proved to be important in Bakhtin's development was the emphasis of its founder on unity and oneness. Bakhtin was not merely a passive receptor of Neo-Kantian ideas, of course, and one of the most important ways he demonstrates his independence from Cohen, even at this early stage, is by resistance to the idea of an allencompassing oneness, or Allheit. In this, Bakhtin is perhaps best understood as a figure who is trying to get back to the other side of Kant's synthesis, the world, rather than the mind (and in particular the rational mind), the extreme to which Cohen tended. The Kantian concept of the heterogeneity of ends is much closer to Bakhtin's work than the Neo-Kantian lust for unity. The essays in this collection can thus be seen as an attempt to rethink the possibility of wholeness in terms more complex than those provided by the Marburg school for by other philosophers of the early nineteenth century, as we shall see below). Kant's definition of relation between mind and world had the effect of defining the know- 
ing subject as a maker of sense out of the otherwise inchoate matter of the world. In his obsession with perception as an act of authoring in these essays, Bakhtin is closer to Kant himself than he is to Cohen, insofar as he rethinks the problem of wholeness in terms of what is an essentially aesthetic operation. In these essays, the individual subject is conceived as similar to the artist who seeks to render what is not an artwork in itself (independent of the artist's activity/ into something that is the kind of conceptual whole we can recognize as a painting or a text. Cohen's lust for unity with its attendant rationalism was not what drew Bakhtin to the sage of Marburg. It was rather his emphasis on process, the radical "ungivenness" of experience, with its openness and energy - the loopholes in existence-that attracted Bakhtin.

\section{II}

During all the years he was in Nevel' and Vitebsk, Bakhtin was constantly writing. We know from references in contemporary journals, newspapers, and personal correspondence that between I 918 and 1924 he worked on several projects. Some of these were not published and have been lost, such as a monograph (possibly two) sometimes called "Patterns of Verbal Creation" and at other times "Aesthetics of Verbal Creation." Other projects, such as a book on Dostoevsky begun at this time, were later published in revised form.

This anthology contains three pieces from the years in Nevel' and Vitebsk: "Art and Answerability," a very short piece that appeared on September 3, 1919, in the one and only edition of the Nevel' journal Day of Art, which is the only piece by Bakhtin to be published under his own name until the Dostoevsky book came out ten years later. It was lost in these obscure provincial pages until republished in $1977 .{ }^{\circ}$

"The Problem of Content, Material, and Form in Verbal Art" was scheduled for publication (but did not appear) in I 924 . It actually saw the light of day in 1975 , the year Bakhtin died. ${ }^{9}$ It seems to have been put together in the form we now have sometime in 1923, although it appears to be closely related to the material on verbal creativity Bakhtin was writing at least two years earlier. "The Problem of Content, Material, and Form in Verbal Art" is difficult to date with any precision, but it can reasonably be specu- 
lated that it was begun fairly early in Nevel' and that Bakhtin continued to work on it after his move to Vitebsk (1920) until he left for Leningrad in 1924.

Another fragment, provisionally entitled by its Russian editors "Toward a Philosophy of the Deed," was published for the first time only in I 986 and will appear in translation in the next volume of the Texas Slavic Series; ${ }^{10}$ its composition would seem to precede "Author and Hero in Aesthetic Activity," which was published in two parts: a long monograph under that title was included in an anthology of Bakhtin's writings that appeared in 1979."

The textual history of Bakhtin's early works is obviously quite complicated-suffice it to say that they all come at the same set of problems from different angles. Thus, it is extremely difficult to discuss any one of them without reference to the others, which is why in the remainder of these remarks I shall not only refer to the works included in the present volume, but shall allude from time to time to the forthcoming translation of "Toward a Philosophy of the Deed."

Why are these essays important? And for whom? A full answer to the first question will, I hope, emerge in the reader's encounter with the texts themselves; I shall offer some partial preliminary answers in what follows. The second question-for whom are these pieces important? - can be answered more readily: the material in this volume was first of all important for Bakhtin himself. It is the precondition for his later work, insofar as it contains many, if not most, of the ideas he would spend the rest of his life exploring, revising, or even contradicting. These essays are also important because, with their appearance, any opinion of Bakhtin formed on the basis of his previously published work must now be modified or discarded.

For Bakhtin, these pieces preserved the fundamental principles of the dialogism that guided his work throughout an unusually long working career. ${ }^{12}$ They date from 1919-1924, the so-called philosophical period of his life, or, in other words, from his first years as a mature thinker-although Bakhtin, who was born in 1895 , was still only in his twenties when they were written. Some idea of the value Bakhtin himself attached to these early works may be gathered from the special care he accorded the notebooks in which he wrote "Author and Hero in Aesthetic Activity." In general, Bakhtin was notoriously cavalier about his manuscripts; 
yet for fifty years - through his frequent moves, his arrest, and exile-he kept with him the yellowing pages of the schoolboy notebooks containing the manuscript of "Author and Hero."

But if these pieces are so important, why was their publication so long delayed? Why did "Author and Hero" appear, in fact, only in 1979-and "Philosophy of the Deed" even later? There are both historical and personal reasons for the fifty-year interval separating the act of writing from the event of publishing these works. In the first decades after the revolution, there could be no question of publishing material so likely to evoke the dreaded charge of "idealism." Some idea of the difficulties Bakhtin had to confront can be gathered from the fate of "The Problem of Content," another piece included here, which was calculated at the time to be a less provocative work than "Author and Hero." Thus, Bakhtin submitted it, and it was actually accepted for publication. But even this relatively "safe" piece was suppressed, when Russkij sovremennik, the journal in which it was to appear, was closed down by the government before the essay could see the light of day. It was only when he was close to death, and reassured by the fame his republished Dostoevsky and Rabelais books had brought him, that Bakhtin revealed to his friends the existence of his earlier manuscripts. ${ }^{13}$ In 1972 , he turned over what was left of his work to two young scholars of the Gor'ky Institute of World Literature, Vadim Valerianovich Kozhinov and Sergei Georgievich Bocharov.

But in addition to the external difficulties that kept Bakhtin from attempting to publish his earlier work, there are reasons for their delayed appearance inherent in his own philosophy and character. As any reader of these essays will quickly become aware, various differences between works that are "consummated" ( $z a$ vershën) as opposed to those that are "unconsummated" (nezavershën) are a major concern in Bakhtin's thought. In the case of "Author and Hero," we have a text that is "unconsummated" not only in the sense that it is still patently at the first stage of composition (portions of it are merely notes or fragments intended to be fleshed out at a later datel: it is also "unconsummated" according to Bakhtin's own architectonic/aesthetic definition of completedness. At this stage of his career, Bakhtin had not yet gained that distanced point of view, that position of "outsideness" (to use another key concept from these essays themselves/ vis-à-vis the concept of dialogue that would come to guide his work in the 
years to come. Bakhtin is already "Bakhtin" here, but it is in the nature of his own complex views on biography-as-task that not all of Bakhtin should be here yet. In fact, in one of the last notes he made to himself just before his death, he himself admits to an unfinished quality in the actual formulation of his ideas; he acknowledges his "love for variation and for a diversity of terms in dealing with the same phenomenon." But he is also aware that there is a "well-known internal unconsummatedness of many of my thoughts [because my ideas have always been] in a state of becoming." And he adds that "it is sometimes difficult to distinguish between the one kind of unconsummatedness and the other."14

It is particularly difficult to draw such a line in these early essays. But we now have certain advantages that Bakhtin himself lacked as he-a constant meditator on the meaning of borderssurveyed his career. We have the architectonic privilege of being outside Bakhtin's achievement, to a degree he himself-by the conditions he laid down in his own work-could never be. With the appearance of these major early texts, the profiles of his work take on a new clarity; something like a canon has now emerged, and we are enabled an excess of seeing vis-à-vis his work that opens new possibilities for consummating it. The question now becomes: what shall we make of this gift of otherness?

Some will feel less addressed by this question than others, and it is possible, of course, simply to avoid it. One need not have an image of Bakhtin's total oeuvre in order to appropriate isolated aspects of it. But for those concerned with understanding Bakhtin in his own right, the texts in this anthology will pose problems of a certain urgency. Taken together, they provide a general theory of human subjectivity, in which various kinds of perception play a major role in order better to distinguish the specificity of aesthetic perception. But as the reader will soon discover, "aesthetics," as Bakhtin conccives the topic, is far more capacious than is usually thought, including fundamental questions of epistemology, ethics, and, indeed, ontology (although one would like to see the ontological assumptions ruling Bakhtin's work treated at greater length than is the case in the existing fragments).

These essays are only part of a great untitled work Bakhtin never finished, a project we have called "The Architectonics of Answerability" for reasons internal to the remaining fragments. It was to have been "a first philosophy," a "philosophy of the actdeed, and not of the deed's product." ${ }^{15}$ Aristotle argued that phi- 
losophy was superior to history because it could generalize about what might be, whereas historians were condemned to what had actually been. In this (and in other ways), Bakhtin defines himself as an anti-Aristotelian, for it is precisely what is realized as opposed to possibility that Bakhtin most honors. Thus, although I have talked about Bakhtin's "theory," I do so only for want of a better word: "theory" is a term that must be invoked with great caution in a Bakhtinian context, for Bakhtin's work is-particularly in these essays-militantly opposed to most conceptions of-precisely-theory. His achievement can be called theoretical only in the sense that all grand anti-theories are inevitably implicated in what they oppose. A large part of these essays is devoted to a new definition of the human subject. But it is precisely the radical specificity of individual humans that he is after: a major paradox in all Bakhtin's work is that he continually seeks to generalize about uniqueness. There is a very real sense in which the necessity of doing so is what his work is about. What might be called theoretical tact, the positing of problems in precisely the right measure of generality and specificity, is an obsessive item in Bakhtin's thought, early and late.

The lack of such tact is often the basis for his criticisms of other theorists. In many of his books devoted to a single problem, he almost invariably characterizes his entrance into the conversation about the problem with the same prescription: a plague-onall-your-houses gesture that points to the need for balance of a kind that Bakhtin argues has heretofore been missing and that he will now provide. Often, this entrance into the dialogue takes the form of the "Goldilocks" formula as she intervenes in the patterns of the three bears: "Not too hot, not too cold, but just right!" Thus, to take only the best-known example, in a muchquoted instance from the 1929 "Voloshinov" book Marxism and the Philosophy of Language, there is an initial discrimination made between scholars such as Saussure who are too general (abstract objectivists) and others who are too limitedly specific, such as Vossler (subjective idealists); Bakhtin/Voloshinov's concept of meta- or translinguistics is then proffered as avoiding both extremes. Bakhtin opens his 1952 discussion of "The Problem of Speech Genres" by proclaiming the staggering diversity as well as the overwhelming specificity of language use: "All the diverse areas of human activity involve the use of language." How, then, is one to say anything general about something so unique in all its 
instances? By positing a subject that can-up to a certain pointbe theorized without doing violence to the very heterogeneity it seeks to meditate: in the case of this late essay (as in his earlier work on language), that subject is "the utterance." The value of making such a move is that it, in its turn, opens up a further field of generalizable propositions that still maintain contact with diversity: "Each separate utterance is individual, of course, but each sphere in which language is used develops its own relatively stable types of these utterances. These we may call speech genres." 16

These-and all Bakhtin's other attempts to find a workable dialogue between general formulations and the specific data that give them rise-are prefigured in the works that make up the present volume. But in these early essays, the extremes of generality and specificity Bakhtin posits are greater, and therefore the problem of how they relate to each other is more openly addressed. He does this in two ways.

First, in "Author and Hero in Aesthetic Activity," Bakhtin works out his own position by defining it against existing schools of "expressionist" and "impressionist" aesthetic thought thatin what is perhaps the first of his "Goldilocks" scenarios-err in the first instance by being overly "internal" and subjective (Lipps or Volkelt), and in the second by focusing too exclusively on external formal features (the Formalists).

Second, and more interestingly, by addressing a number of criticisms against theory itself, Bakhtin attempts-theoretically-to work through the dilemma of how to generalize the need to be specific. Kant had sought to rein in the speculative hubris of the Western philosophical tradition by demonstrating the limits of metaphysics. His value for Bakhtin is that the hardheaded citizen of Königsberg (in an example Bakhtin quotes) had insisted 100 Thalers in thought were not equal to roo Thalers in experience. It is this call to intellectual modesty in Kant, and its implications as worked out in Neo-Kantianism, that draws Bakhtin back again and again to the three great Critiques, especially The Critique of Pure Reason and The Critique of Practical Judgment.

But in order to purge metaphysics, Kant had been forced to resort to a transcendentalism of his own, and it is this tendency in Kant and other thinkers that Bakhtin most strenuously opposes. Bakhtin's thought is a "philosophy of the deed" insofar as he again and again draws a distinction between experience and reflection on experience, or cognition. "The discovery of an a priori, 
transcendental element in our understanding did not open an exit from the interior of our understanding . . ."Kant's transcendental subject is the positing merely of "a gnoseological subject," 17 because "epistemological reflection has nothing to do with the individual form of experiencing an object ... it has to do with the transcendent forms of the object (and not of the experience) . .." It is the transcendentalized Kant Bakhtin is still setting himself against in such later essays as his monograph on the chronotope, where he makes the point that he is "employing the Kantian evaluation of the importance of [time and space] in the cognitive process, but [I] differ from Kant in taking them not as 'transcendental,' but as forms of the most immediate reality." 18 What Bakhtin means by his apparently casual reference to the difference between a "transcendental" level and the level of "immediate reality" (samaia real'naja dejstvitel'nost') is made clearer in these early essays in those places where Bakhtin distinguishes between all cognitive levels of awareness and the kind of situated awareness individual human beings experience in the unique sites they occupy in the world at a particular time and in a particular place.

In "Author and Hero in Aesthetic Activity" the distinction is first of all charted in terms of visual perception. If two persons look at each other, one sees aspects of the other person and of the space we are in that the other does not and-this is very important-vice versa: "As we gaze at each other, two different worlds are reflected in the pupils of our eyes."

The implications of the difference between these two worlds reverberate throughout these essays, but at a first appropriation this expression signifies that I can see things you do not, such as parts of your body and details of the room or landscape your angle of vision denies you; the same, of course, can be said of you as you regard me from the position you occupy. Each of us has an "excess of vision" relative to the other. We can, conceivably, construct an image of the situation that will fill in the details we cannot actually see. At this level of generality, the positions we occupy are convertible: in describing things in this way, Bakhtin is at-we are at-the level of cognition that generalizes the subject. For cognition, "there is no absolutely inconvertible relationship of $I$ and all others; for cognition, ' $I$ and the other,' inasmuch as they are being thought, constitute a relationship that is relative and convertible, since the cognitive subiectum as such does not oc- 
cupy any determinate, concrete place in being. "But for a particular person, in a particular place at a particular time, and thus constrained by all the conditions peculiar to such a unique placement, "the interrelationship of ' $\mathrm{l}$-the other' is not convertible for me in lived life in any concrete way." Since it is not convertible, it must be viewed perspectively.

If the central role of architectonics in these essays is not recognized, Bakhtin's obsession with simultaneity of various kinds can all too easily be misread as (yet another example of) a mechanical concern for binary oppositions. ${ }^{19}$ But what is essential for Bakhtin is not only the categories as such that get paired in author/hero, space/time, self/other, and so forth, but in addition the architectonics governing relations between them. What counts is the simultaneity that makes it logical to treat these concepts together. The point is that Bakhtin honors both things and the relations between them--one cannot be understood without the other. The resulting simultaneity is not a private either/or, but an inclusive also/and. In other words, the logic of Bakhtin's simultaneity isdialogic. But conceiving architectonics dialogically does not eventuate in the simplistic pluralism some of Bakhtin's more liberal (and less informed) readers have wanted to see in his work. Invoking two more key Bakhtinian terms, we may say that wholes are never given, but always achieved; work-the struggle to effect a whole out of the potential chaos of parts-is precisely what, in fact, architectonics theorizes.

The overwhelming general significance of architectonics must be remembered, then, in any discussion of the specific terms shaping Bakhtin's practice. It is only slightly less vital to keep in mind that architectonics is intended to describe an activity: the relations it orders are always in a state of dynamic tension. Architectonics is like architecture insofar as it is about building wholes through the manipulation of relations between parts. But architecture suggests the creation of static structures. The matter of architectonics is active in the sense that it is always in process (architecture is only one instantiation of architectonics, and aesthetics, as we shall sec, is another)-not in any of the actual materials it employs to erect relations in themselves exclusively; even though such materials may be the most abstract categories, such as "being" or "relation" itself, they can still be treated as entities. When conceived as in themselves, they are like the stone and wood deployed by the architect insofar as they are-outside archi- 
tectonics-inert. Therefore their materiality must be thought in relation to the ends of which their physical aspect is only a /dialogic) part. In other words, they must be conceived as having not merely a physical presence as things in themselves, but also a relation to other things. The invisible relation between them, the immaterial lineaments of the simultaneities that bind themthese are also the stuff of architectonics. Being, as Bakhtin never tires of repeating in these essays, is in its essence active: architectonics names the body of techniques by which its sheer flux may be erected into a meaningful event.

The specific subset of architectonics that most occupies Bakhtin in these essays is the aesthetic event. He distinguishes here between a "general aesthetics" that lays down the conditions for all aesthetic events and a "special aesthetics" that accounts for the distinctive qualities of the material used in a given art form within those conditions. As befits a thinker so preoccupied with architectonics, Bakhtin advances his argument by constantly making discriminations between these different levels of relations.

The aesthetic, as defined here, is a category that has less to do with the traditional concern of aestheticians for "beauty" than it has to do with the mysterious concepts of "isolation," "outsideness," and "consummation." The activity of perception-understood as the activity of a subject engaged in making sense out of the world by fixing the flux of its disparate elements into meaningful wholes-is treated by Bakhtin as the activity of creating a text, much as authors make texts out of the givenness of the world outside art. Aesthetics in Bakhtin's sense always entails perceiving an object, a text, or even a person as something actively fashioned into the whole of the object it is. This shaping or finishing-off or, as it is rendered in this translation, this consummation is then treated as an act of authorship. It will perhaps come as something of a surprise to casual readers of Rabelais and His World that not all totalizing strategies are inherently bad. The positive, creative aspect of aesthetic consummation can be grasped only by rethinking authorship, one reason why it is a key concept in these essays. The general aesthetic Bakhtin provides is grounded in the primal condition that holds for all perception of any kind, a condition that might be called the first law of human perception: whatever is perceived can be perceived only from a uniquely situated place in the overall structure of possible points of view. The enabling condition for having a point of view on any- 
thing is to be able to see-and one can see only from a particular place. The a priori from which the rest of Bakhtin's thought flows is the assumption that each of us occupies a situation in existence that, for the time we occupy such space, is ours and ours alone: what I see is not the same as what anyone else sees. Perception, how I "sce" the world, is always refracted, as it were, through the optic of my uniqueness. Bakhtin calls this uniqueness of vision my "excess of seeing" insofar as it is defined by the ability I have to see things others do not.

He metaphorizes this condition in the encounter of two people looking at each other: "at each given moment, regardless of the position and the proximity to me of this other human being whom I am contemplating, I shall always see and know something that he, from his place outside and over against me, cannot see himself: parts of his body that are inaccessible to his own gaze (his head, his face and its expression|, the world behind his back, and a whole series of objects and relations, which in any of our mutual relations are accessible to me but not to him."

It will be obvious from this example that Bakhtin differs from many other thinkers now in fashion in that he does not begin by rejecting the intuitive sense of things held by most of his readers, who will fecl that they are individuals precisely because-for better or worse - they are the keepers of their own uniqueness. We approach here the eye of the Bakhtinian needle: there are some, steeped in current orthodoxies about the death of the subject, who will sniff the brimstone of a thoroughly discredited existentialism in all this and pass on. Those with more patience will soon perceive, however, that the human subject defined in this way is not condemned to subjectivism, the prison-house not of language, but of the ego: a first implication of recognizing that we are all unique is the paradoxical result that we are therefore fated to need the other if we are to consummate our selves. Far from celebrating a solipsistic "I," Bakhtin posits uniqueness of the self as precisely that condition in which the necessity of the other is born.

But in order to perceive the fatedness of alterity, we must grasp the role of simultaneity in human perception. The "ever-present excess of my seeing, knowing, and possessing in relation to any other human being is founded in the uniqueness and irreplaceability of my place in the world . . . only I-the one-and-only Ioccupy in a given set of circumstances this particular place at this 
particular time; all other human beings are situated outside me." The dialogical paradox of this formulation is that every human being occupies such a determinate place in existence: we are all unique, but we are never alone. Bakhtin's enterprise is founded on the situatedness of perception and thus the uniqueness of the person, but it abhors all claims to oneness. It is not only the case that from my unique situation in space and time I am able to see things you do not: it is also-and simultaneously-the case that from the vantage of your uniqueness you can see things that I cannot.

Rimbaud was not the first to discover that le est un autre. In virtually all traditional societies of the kind that used to be called "primitive," and in most previous stages of our own culture, the otherness of the self has been axiomatic. As a distinguished anthropologist has recently said, "The awareness that ' $I$ is another' is an awareness only a self-interested age obsessively concerned with the autonomy of the individual would regard as paradoxically strange and counter-intuitive." 20

Bakhtin's formulation of the self/other problem is especially insistent about the need always to negotiate relations among unique individuals. We not only interrogate each other, we interlocate each other, and it is the interlocative or dialogic self that is the subject of Bakhtin's architectonics. The interlocative self is one that can change places with another-that must, in fact, change places to see where it is. A logical implication of the fact that 1 can see things you cannot, and you can see things that I cannot, is that our excess of seeing is defined by a lack of seeing: my excess is your lack, and vice versa. If we wish to overcome this lack, we try to see what is there together. We must share each other's excess in order to overcome our mutual lack.

In his later work-most comprehensively in Marxism and the Philosophy of Language and the monograph on speech genresBakhtin will explore the complexities of reciprocity as they manifest themselves in the formal categories of quotation (in written language) and turn-taking (in spoken language). But in these early essays he explores the condition that such discursive markers manifest in the more abstract terms of time, space, and value.

The specific reciprocity Bakhtin explores in these essays is the interlocative relation of "I" to "another" in lived experience. The fatedness of the self/other distinction as it cuts across all human perception is the basis in these essays for Bakhtin's exploration of "author" to "hero." Aesthetics is the struggle to achieve a whole, 
but a whole that must first of all be understood as a purely positional or relative construct: the question must always be asked: by and for whom is this whole consummated? Second, such a whole is never a seamless oneness, insofar as it is always a negotiated relation between "two powers and ... two interdependent systems of laws established by those powers; every constituent in the artistic whole is determined in terms of two value-systems, and in every constituent these two systems are in a state of intense and essential axiological interaction-they are the two paired powers that endow every constituent of the whole and the entire whole itself with the axiological weight of an event." These two powers instance themselves in manifold ways along several different axes, the most basic of which all inhere in features that define the difference between perception from the self and perception from the other.

These terms are currently freighted with so much excess ideological weight that it is difficult to approach any fresh use of them with innocent eyes; but it will perhaps help if we keep in mind that "self" and "other" are not for Bakhtin mysterious categories in which the delusion of immediacy slumbers. Rather, in his use they are the most comprehensive terms for modeling the heterogeneous factors that mandate perception as an event that can only be reciprocal. These essays consist largely of hierarchically ordered catalogues of the attributes that define differences between self-perception and other perception. We shall now hastily review the more important of these attributes, in order to give some idea of their scope and consequences.

\section{III}

First of all, a warning is in order. These attributes occur in pairs; to avoid the tedium of constantly repeating that each of them should not be treated as a neatly structuralizable binary opposition, I have not said as much every time. Therefore, it should be kept in mind throughout this survey that what is at issue is not the paired categories as such, but rather the reciprocal simultaneity that yokes each of these pairings in dialogue not only with each other, but with other categories as well.

Discussion has already begun-and these essays will add fuel to the argument-as to which particular -ism, of those that cur- 
rently occupy our attention, may most readily accommodate Bakhtin's somewhat eccentric oeuvre. But he is indisputably NeoKantian at least in this: for all his reservations about "epistemologism," Bakhtin's major concern is to make sense-and use-of the individual subject's perception of the world. Architectonics is the key to Bakhtin's philosophical anthropology because at the heart of all human action is the problem of achieving wholeness of one kind or another out of parts of different kinds. But the basic difference is between self-perception and other perception. This division cannot be overcome; it can only be mediated. Architectonics is how particular differences flowing from this Urdifferenz are negotiated into specific relations. Bakhtin's account of architectonic activity is, thus, radically perspectival and situational.

Everything must be approached from the point of view ofpoint of view. And point of view is always situated. It must first of all be situated in a physical body that occupies time and space, but time and space as embodied in a particular human at a particular time and in a particular place: the main thrust of Bakhtin's whole architectonics is captured in his dictum that architectonics is the ordering of meaning; "as the intuitionally necessary, nonfortuitous disposition and integration of concrete, unique parts and moments into a consummated whole, [architectonics]can exist only around a given human being as a hero" (emphasis added).

In other words, we always conceive the world intentionally, as it relates to the desires and purposes of human beings, without whose ends things would indeed be "in themselves." The subject as "I" literally embodies in a meaningful particularity that is otherwise a limitless generality, for thought in itself is always potential, and therefore not inherently limited: it contains "the energy of extraspatial and extratemporal infinitude, in relation to which anything concrete is merely fortuitous; a thought can provide no more than the direction for seeing something concrete, but a direction that is infinite, a direction incapable of consummating a whole." An important way in which the potential infinity of thought bears on the actual finitude of my being is the relation my consciousness bears to the moment of my birth and the moment of my death. As a body that was born into the world at a particular time and place, and that will pass away in an equally specific time and place, I literally embody a unique slice of time/ space. As the means, therefore, of particularizing the otherwise 
infinitely general aspects of time/space, I become the instrument for assigning specific value to abstract time and space. In themselves, they have no value, for value is always for someone: "Strictly speaking, geography knows no far or near, here and there. ... And history, likewise, knows no past, present, and future. . . The time of history is itself nonreversible, of course, but within it all relations are fortuitous and relative (and reversible), for there is no absolute center of value lof the kind provided by the situatedness of the individual subject|."

But there is a problem here: as the precondition for architectonically ordering the world, there are important differences between the way I order my own place in it and the way I order the place of others who are-from my place in existence-not the same kind of center for specifying value that $\mathrm{I} \mathrm{am}$. While it is my mortality that permits me to embody time and space as particular values, the activity that is my "self" works as if it were co-terminous with consciousness, which-insofar as it comes after birth and expires before death-means it is manifested as a perpetual present, without beginning or end. The other, however, I perceive as limited in time: I can see his beginning and end, and even the repeatable rhythms of bchavior that fix him as an activity identical with his physical body. So, at least, it manifests itself to me; not only temporally, but spatially I perceive those who are not me in completely different terms. I see the world from a "horizon": the world gives itself as immediately around me, as circumscribed by the unique angle of my vision, as a surrounding full of specific meanings determined by my own ends. The other, however, I see as existing in an "environment": the world is the same for him as it is for others, for it is not conditioned by the uniqueness of his intentionality (as is my horizon). The other is in the world at large, including all other beings and things, while I exist in a world that enfolds me in a unique relation to my ends and is thus experienced as having an intimacy and reality different from that of the "environment" in which others are consummated as finite entities.

In its own terms, my self is not reducible to the temporal or spatial restraints that make consummation of the other possible. From itself, in its own terms, it cannot be consummated. Yet it must be, for only that which is consummated can be perceived. Long before Sartre, but with overtones that (as we shall see) nevertheless are post-Sartrean, Bakhtin makes use of terms we now as- 
sociate with Being and Nothingness (pour-soi, pour-les-autres, etc.), as in his discussion of how the self is forced to perceive itself in the categories of the other. I clothe my inner body, says Bakhtin, in the time, space, and values that are the same I use for others, but behind the I-for-others that results from such appropriation, my I-for-myself, as the enabling condition of my existence, continues to act as the seat of perception and ground of action, and thus in a time/space that is always open, so long as I consciously inhabit the site of its unique place in existence.

In both cases, notice, I consummate-or give finished form to-another. It is this fact that induces Bakhtin to make one of his bolder hypotheses: to treat the activity of perception as the structure of authoring. I give shape both to others and to my self as an author gives shape to his heroes. As Bakhtin began his career by announcing, life is not art, and art is not life, but the two cannot be separated from each other. Unlike Plato in the "Phaedrus" and Paul Ricoeur in a number of influential essays treating meaningful action as a text, ${ }^{21}$ Bakhtin does not believe writing rescues the event from its spatial limitations in a particular site or its temporal limitations in mere memory. The textualization that the work of art accomplishes needs itself to be rescued from the sterility and fixity of its formal manifestation: it is as an "event that we must understand and know the work of art," that is, as "an effective moment in the unitary and unique event of being, and not as a thing-an object of purely theoretical cognition devoid of the validity or force of an event, devoid of any weight with respect to value." Long before Derrida's Of Grammatology, Bakhtin was working against the ideology of literacy.

The activity of shaping is not the same operation in lived experience as it is in more mediated expressions. But both activities are driven by a perceptual mandate to consummate. It is aspects of the dialogic need to give form to experience that are shared with the need to give life to forms, that account for the urgency Bakhtin assigns aesthetics in these essays. The relation of author and hero in a literary text, when re- or co-authored by readers, that is, when appropriated by them as the tensile relation of an " $I$ " to another, serves as a particularly clear-cut paradigm of what Bakhtin means by the architectonics of answerability: for I give life to the text by seeking to find the appropriate balance of relations (architectonics as aesthetics) between author and hero in the lived experience of my reading. "Every word in narrative 
literature expresses a reaction to another reaction, the author's reaction to the reaction of the hero; that is, every concept, image, and object lives on two planes, is rendered meaningful in two value-contexts - in the context of the hero and in that of the author." It is the reader's reaction to reactions in the work of art that transforms a text into an event by giving it meaning.

It is the meaning or, in other words, the particular configuration of time, space, and values that I construct through architectonically shaping relations between author/hero as self/other-as they are both other to myself as reader-for which I, in the unique place I occupy in cxistence, am answerable. The author, insofar as he becomes in such a reading a subject, is-like all other subjects-not an identity, that is, not coincidental with the biological figure whose name appears in the slot conventionally reserved for authors. He is the author only in the event of the artwork-only as he can be perceived or shown to be a function of the relation between author and hero in the event of a particular reader's reading (co-authoring) of that particular text. There are, of course, relations between the formal elements of the text-deployment of pronouns, the tense and aspect of verbs, discursive style of dialogue-and the time, place, and historically instanced writer involved in the text's first production / which was already a reading), but these are highly mediated and of an extraordinary complexity. Since all texts are conceived by Bakhtin to be utterances, and all utterances are linked to each other in the great heteroglot dialogue of dialogues constituted by all that has been said and all that will be said in history, the "origin" of a text is always only another link in the long chain of its possible transmissions.

\section{IV}

The general theory of authoring proposed by Bakhtin in these essays raises new possibilities for perceiving Bakhtin himself as an author. If we take these early essays of Bakhtin seriously, we ourselves are called upon to consummate, or co-author, his work. And in order to do so, we are compelled to treat him as a character or-again in his sense of the word-to treat him as a hero-in other words, as a subject who is aesthetically consummated by another: some way must be found to perceive wholeness amidst the variety of his several works. The difficulty of doing so is com- 
pounded by the equally strict Bakhtinian expectation that no whole should homogenize the variety of its parts-it should not, in other words, reduce their heteroglossia to the level of a monologue. The dual asymmetry of this demand is not a double bind, nor is it a binary opposition-it is the complex form of simultaneity not only at the heart of Bakhtin's argument in these essays, but in the circling, spiraling style of the particular form that argument assumes. The paradox that obssesses Bakhtin here is one that his readers cannot avoid: we must do what these essays are about. In other words, if we read Bakhtin, we must find a way to generalize his own particularity.

There are at least three directions this undertaking might assume: to specify more precisely the particular role of Bakhtin in the "Bakhtin circle"; to understand Bakhtin's relation to other thinkers in the past who have wrestled with some of the same issues he engages; and, finally, to place him in relation to current work on the topics he explores. An introductory essay is not the appropriate place to pursue any of these itineraries very far, but an attempt will be made to indicate what the outlines, at least, for further work in the first two of these directions might be. I shall conclude this essay by suggesting why I avoid the temptation of seeking to formulate a place for Bakhtin in current theory. Suffice it at this point to say that to do so would be to author inevitable inaccuracies: insofar as Bakhtin is still a "living" figure, any statement of his current status is ineluctably a gesture toward a future that cannot be known from the place of contemporaneity.

These early works cannot help but add fuel to the debate about Bakhtin's role in those texts claimed by some to be his that were published under the names of his friends Ivan Kanaev, Pavel Medvedev, and Valentin Voloshinov. The debate has increasingly become a sport only for the initiated, requiring a highly detailed knowledge of the whole Bakhtinian canon, plus an immersion in the lives and worlds of the men involved. ${ }^{22}$ Arguments for the sole authorship of Medvedev and Voloshinov based on considerations of style will be strengthened by patent disparities between these early philosophical texts and the later "deuterocanonical" works. Others will find fresh cause for their belief in Bakhtin's major role in the disputed texts' composition. This is not the place to rehearse arguments for both sides, but any position one assumes now will have to take into consideration Bakhtin's complex theory of authorship as it is laid out in these essays. I myself con- 
tinue to believe Bakhtin played the major role in such texts as The Formal Method and Marxism and the Philosophy of Language, adopting Medvedev and Voloshinov as co-authoring others (in the sense in which he uses that term in "Author and Hero in Aesthetic Activity") who permitted him to gain a position of outsideness on the subjects treated, a transgredience he would not have achieved without them.

Other thinkers Bakhtin engages in these essays have various degrees of importance in his later work. The concern here for obscure aestheticians of expressionism will in later texts be translated into more interesting attacks on specific versions of idealist ideologies, such as his criticisms of Vossler and (especially) Saussure. Although the Marburg school will become less and less important for Bakhtin in later years, Cohen's emphasis on Kant's distinction between what is given and what is created will play a role in Bakhtin's work until the end..$^{23}$

Another philosopher who figures prominently in these essays and who will continue to shape Bakhtin's thinking is Bergson. Bakhtin's emphasis here on the body, with his very important distinction between "inner" and "outer" body, cannot be understood without reference to the concept of body in Bergson, particularly in Matter and Memory (r896). Bergson is important because of his general project of seeking to retrieve for philosophy the problem of mind/body relations that in the waning years of the last century was falling into the hands of the psychologists-indeed, into the hands of many of the same psychologists against whom Bakhtin, too, will take arms. Bergson's attempt to think the materiality of the human body as a philosophical problem is important for Bakhtin in the degree to which it seeks to overcome Cartesian dualism through a series of stratagems that we can now recognize as dialogic. On the one hand, Bergson recognizes that the body is first of all an object among other objects; thus, it may serve as the orientation point for making judgments about the location of things: "the size, shape, even the color of external objects is modified according as my body approaches or recedes from them; that the strength of an odor, the intensity of a sound, increases or diminishes with distance; finally, that this very distance represents, above all, the measure in which surrounding bodies are insured, in some sort, against the immediate action of my body ... [images of external objects] take rank in an order corresponding to the growing or decreasing powers of my body." 24 
The physical body is important, then, as occupying a unique place in existence. But the sheer physicality of my body cannot be understood as the locus of my existence without also taking into account the fact that as a living organism I must, whether I will it or not, pay attention to life. ${ }^{25}$ I cannot be indifferent to my surroundings. Thus, the body is best understood as the center of my actions. Bergson goes so far as to define psychosis not as "an inward disorder, a disease of the personality," but as precisely "the breaking of the tie which binds this psychic life to its motor accompaniment, a weakening or impairing of our attention to outward life" (Matter and Memory, pp. xvii-xix). But insofar as my body is the center of action (what Bakhtin calls a deed), "it cannot give birth to a representation" (Matter and Memory, p. 5). The body, then, is dependent on activity other than its purely physical functions (as they are usually understood, at any rate), for shaping the world into coherent images. A total description of an act would have to include a body, objects (or images of objects) external to it, and a change in the relations between the body and the other images. Furthermore, "I see plainly how external images influence the image that I call my body: they transmit movement to it. And I also see how this body influences external images: it gives back movement to them" (Matter and Memory, p. 5). The mind (or soul, as Bergson calls it) plays a role in this activity since a judgment must be made first of all about what is influencing what - is it my body that opens the door, or does the door get pushed open knocking me down? Second, and more importantly, of course, once the brute direction of influence is decided, the effects of such influence must be evaluated. In this sense the body is but a privileged image, providing for the exercise of choice among possible reactions.

But the body is an image that is after all privileged, and Bakhtin attempts in these essays to answer why it should be so. Although close to Bergson in many ways, Bakhtin is dissimilar in the emphasis he assigns to different aspects of the same problem. Thus, Bakhtin concentrates less on body/mind oppositions (for him, they are less oppositions than differing stages of a continuum), preferring rather to highlight the self/other distinctions in which he sees the body's privilege residing. The emphasis on otherness in these essays puts Bakhtin squarely into the tradition of much modern thought. Even an incomplete list of thinkers who have dealt with the problem would have to include minimally Edmund 
Husserl, ${ }^{26}$ Max Scheler, ${ }^{27}$ Maurice Merleau-Ponty, ${ }^{28}$ and Jacques Lacan. ${ }^{29}$ Three figures of particular importance in understanding Bakhtin's place in this tradition are Martin Buber, Jean-Paul Sartre, and Martin Heidegger. The connection with Buber has already received some attention, ${ }^{30}$ so I shall not dwell on it here, except to say that both Buber and Bakhtin owe an obvious debt to Hermann Cohen's meditation on the otherness of God..$^{31}$ It is equally obvious that both insist on the ethical need to treat the other person not as "you" but as a "thou." But both Cohen lat least in his last phase, after his move to Berlin in I $9 \mathrm{I} 2$, when he was working on The Religion of Reason Out of the Sources of Judaism) and Buber rely heavily on Torah and Jewish midrashic tradition for their inspiration and authority. This context makes for a number of inevitable differences between them and Bakhtin's essentially Russian Orthodox frame of reference when he deals with matters that have occupied religious thinkers of the past. Of course, the whole emphasis on architectonics and aesthetics in these early Bakhtin essays is quite different in its implications from anything in Cohen or Buber.

We know that Bakhtin had read Buber by the time he came to write thesc carly essays. But two thinkers whose work he could not have known in the years he was writing them would seem to bear a much closer relation to the concerns of these essays than docs Buber. Heidegger's Being and Time was published only in 1927, eight years after the last of the pieces included in this anthology, and Sartre's Being and Nothingness did not appear until 1943, two decades after Bakhtin had completed these essays. Yet the surface similarities between the main outlines of Bakhtin's initial project and the Heidegger and Sartre books are striking, extending in some cases even to the same terminology. Before surveying some of those parallels, it will perhaps be useful to ask why they should be there at all-despite the fact that, at the time he was working on these essays, Bakhtin could not possibly have read the relevant texts by either Heidegger or Sartre, since neither had yet been published. The beginnings of an answer are to be found, I bclieve, in the urgent sense of a general crisis animating the work of each of these men, and the specific means each chose to meet that crisis. Bakhtin is working in the immediate aftermath of World War I and the Bolshevik Revolution; Heidegger writes his book in the shadow of the same war and during the extended political and economic anxiety we call the Weimar Repub- 
lic; and Sartre finishes his masterpiece during the Nazi occupation of France. In addition, each thinker was unusually sensitive to the new challenges to metaphysics raised by contemporary science and technology. Each was convinced that there could no longer be any question of doing philosophical work as usual.

What disturbed these three thinkers (among others, of course) was the combined negative effect that events in their lifetime were having on traditional ideas about the nature of individual human existence. In ancient Greek or later Christian versions of the soul, as well as in secular Enlightenment ideas about the exalted "nature of Man," a certain importance, if not always dignity, attached to human existence. But any privilege that might still have clung to being human was swept away after the sheer indiscriminateness of the military slaughter that went on from 1914 to I 9 I 8, to say nothing (in the case of Sartre) of the radical dehumanization dramatized in Hitler's death camps and torture cellars. The effects of these horrors can be traced in the urgency with which Bakhtin, Heidegger, and Sartre felt they had to do philosophy in a different way. They sought to avoid the abstractness and the exclusive dependence on rationality that had characterized Western metaphysics, which seemed to have very little to do with the world as they found it.

The specific way they chose to go about the task results in some dramatic similarities among them: each sought to rethink the particularity of the individual human subject outside traditional categories for doing so. The self/other relation as it is experienced in the immediacy of unique lives becomes the subject of their investigation, much as truth, justice, and the good had been the subject of earlier thinkers. The self/other relation is a topic whose pursuit has built into it a certain number of ineluctable moves, such as an analysis of the self's relation to a body, the problem of mirror images, or a phenomenology of the gaze. All these topics raise questions about the perception of time and space. In these essays (and at this level of generality), Bakhtin can be observed going through precisely these moves, as, later, Heidegger and Sartre will. Of course, there are considerable differences among the three, and we shall also look at these as we briefly survey their work in relation to each other.

Heidegger's goal of getting at Being through the particular kind of being that human existence constitutes led him to reject Kantian transcendental categories for existentials, or the determi- 
nants of Being in lived experience. One direction that further work on relations between Bakhtin and Heidegger might well take would be to conceive the various constituents of Bakhtin's architectonics, such as consummated/unconsummated, or inner/ outer bodies, as existentials in the Heideggerian sense. Heidegger's definition of the individual human as Dasein is predicated on the assumption that being-there means being-in-the-world, which is always a being-with. Like Bakhtin, Heidegger emphasizes worldliness, and the degree to which self-knowledge comes through others: "Knowing oneself [Sichkennen] is grounded in Being-with, which understands primordially", ${ }^{32}$ in his "Beingthere-too" (Auch-da-sein) we have an almost precise parallel with Bakhtin's "And-I-also am" ( $i$ ja esm'). Heidegger's preoccupation with the time-drenched nature of mortality-the span between birth and death in a particular being-there-as the basis for uncovering meaning in human existence has its analogue in Bakhtin as well.

In discussing the value of time and space, Bakhtin says, "Once you annihilate the moment constituted by the life of a mortal human being, the axiological light of all rhythmic and formal moments will be extinguished. The point here is not, of course, the mathematically determinate duration of a human life, for that duration could be shorter or longer; the only important thing is that a life and its horizon have terminal limits-birth and death. It is only the presence of these terminal points, along with everything conditioned by them, that creates the emotional-volitional tonality of time's passage in a circumscribed life ... even eternity and limitlessness acquire their axiological meaning only in correlation with a life that is determined."

Parallels between terms used by both thinkers such as "proximity," "on-handness," and many others will be clear enough. But such similarities should not mask differences between the two that are fundamental. The first of these would have to be the emphasis each attaches to embodiment. Heidegger's focus on human existence is motivated by his stated intention to uncover the nature of Being. Having exposed a local instance of being in Being and Time, he proposed in the follow-up volume to engage Being more globally. That follow-up volume, of course, was famously never written. Some of the force of Bakhtin's argument against theory as such might well be brought to bear on Heidegger's particular strategy of using human existence as a means to theorize Being. 
Bakhtin's own course is the reverse of this: he begins with a general account of time, space, and value in human experience, but spends the rest of his life seeking to specify these existentials in studies of particular instances. This turn is perhaps dictated by the more restricted focus of Bakhtin's work in its first stage when compared with early Heidegger: the latter opens his career as a seeker after the ontic; by contrast, even in his most technically "philosophical" pieces, Bakhtin for better or worse does not rise to that level of concern. His architectonics does engage questions of time, space, and value, but there is never any presupposition of an underlying stratum of Being prior to the human experience of them.

There are significant and fairly obvious parallels between these essays and Sartre's Being and Nothingness. The most important of these would once again be the general emphasis on being in the world, the role of bodies, ${ }^{33}$ the determining power of the other's gaze, and the distinction between being-for-myself and being-forothers. The particular way Sartre conceives consciousness as an emptiness that must be filled, ${ }^{34}$ and identity as a task that must be performed, constitutes a further similarity to Bakhtin's early work. But once again, the overarching aim of Sartre's undertaking in Being and Nothingness, which may roughly be stated as the attempt to understand the difference between people / who may be for themselves) and things (which are only for others), makes for differences as well. Primary among these would be the underlying assumption of privilege that Sartre assigns to the in-itselfness of things: Sartre's conscious subject knows himself only as a constantly unrealized project, and others only as a constraint on his own (potential) freedom. The Sartrean subject looks suspiciously like Hegel's Geist, insofar as both seek an end to division and struggle and long for the stillness that is inherent in things that are unburdened by the demands of consciousness. As his novel Nausea makes clear, Sartre's subject is sick because he desires the condition of being a god, having the attributes both of a for-itself and of an in-itself. In Bakhtin, there are no things in themselves, no possibility of an actual object understood as an it-itself; thus, the dialogic subject, existing only in a world of consciousness, is free to perceive others not as a constraint, but as a possibility: others are neither hell nor heaven, but the necessary condition for both. 
As a result of Sartre's adversative definition of the other, he had the greatest difficulty in forging a politics, particularly the theory of collective social action to which his last work was devoted..$^{35}$ While there is perhaps a greater opening toward such an enterprise in Bakhtin's less restricted version of the other, the lack of a more carefully considered treatment of conflict and power relations in self/other dealings is something of a limitation in Bakhtin's thought as well, particularly in these early works, in which questions of class and gender distinctions are also absent.

\section{V}

Perhaps, therefore, the most significant thinker with whom Bakhtin's name has been coupled might still prove to be Karl Marx. The difficulty of conceiving relations between the two are notorious. It is well known that Bakhtin was, like his hero Dostoevsky, a very complicated sort of Christian-as these essays make more manifest than any of his other writings. We now know that the official reason given for Bakhtin's arrest in 1929 was his membership in Voskresenie (Resurrection), an organization of intellectuals who sought to synthesize the principles of Christianity and Marxism. However, in the years just after the revolution, he opposed Bolshevik speakers in public debate on several issues of the day. Yet, in some of the books published under his own name (such as his Dostoevsky monograph), he invokes Marx at some critical points in his argument. In the books published under the names of Medvedev and Voloshinov, Marxism is not only invoked: claims of strengthening or even expanding the scope of Marxist analysis are made. The "authorship question" is thus intertwined with the "Marx question." 36

The problem is complicated by the fact that these essaysmore than any of his other published works-manifest not only Bakhtin's immersion in West European philosophy, but his situatedness in Christian tradition as well. In these early essays, those principles are complicated by a vocabulary that derives not only from philosophy, but from religion. But Bakhtin's relation to the philosophy of religion (which is not the same thing as religion itself) is as idiosyncratic as his relation to a theory of social action. Unlike theology, which might deal with "souls," Bakhtin deals 
with "the problem of the soul." The soul is, of course, one of Christian theology's basic categories; so it is difficult to conceive what Christians will make of Bakhtin's claim that-from the point of view of methodology - the soul has nothing to do with ethics or psychology; in fact, "in my relationship to myself, I have nothing to do with the soul." Rather, "The problem of the soul, from a methodological standpoint, is a problem in aesthetics."

This conclusion will seem less startling if we remember that aesthetics has its own shade of meaning in Bakhtin. It is a key concept in these essays, discussed at more length below. Suffice it at this point that, for Bakhtin, aesthetics is a form of embodying lived experience, for consummating action so that it may have the meaningfulness of an event: "for everything that is aesthetically valid encompasses not a void, but the persistent . . . directedness to meaning on the part of an act-performing life." Or again: "before assuming a purely aesthetic position in relation to the hero and his world, an author must assume a lived-life position, a purely cognitive-ethical position."

With the publication of these essays, then, the strategies by which Bakhtin might be appropriated to Marxism are complicated. For those who would assimilate Bakhtin to-as well as for those who would separate him from-Marxist thought, the least problematic strategy would seem to be to invoke Bakhtin through the agency of a "Bakhtin circle" exclusively; to assume, in other words, that only those texts published under the names of Medvedev and Voloshinov that are self-proclaimedly Marxist (and, it can be argued, were not written by Bakhtin/ may be incorporated into an authentic Marxist framework.

But for those who do accept Bakhtin's major role in the disputed texts' composition, things are not quite so simple-but neither is the resulting contribution to Marxist thought, which might prove to be more useful and interesting than any deriving from the first strategy. Separating a Marxist Voloshinov or Medvedev from a non-Marxist Bakhtin (who, after all, is admitted by all parties to be the major theorist of the three) is ultimately less convincing than to assume a role for them all. These essays open new possibilities for rethinking Bakhtin's relation to Marx. It can now be argued that Bakhtin himself was wrestling with many of the same questions that preoccupied Marx, as these early texts make clear.

This is a possibility that cannot be explored at proper length in 
an introductory essay. But a dialogue between Bakhtin and Marx might prove to be of the greatest value: seeing one in the light of the other may, for instance, lead to a better understanding of a Bakhtinian social theory that is otherwise only implicit. Conversely, Bakhtin may help to provide what has often felt to be lacking in Marx: a more complex theory of the individual subject in such otherwise collectivist phenomena as class struggle. A beginning might be made in the recognition that Bakhtin and Marx arc both sceking to understand the complexities of "value," "exchange," and "otherness" (in particular, various forms of alienation).

The all-pervasiveness of axiology, a theory of values, is selfevident in these essays. In Bakhtin's philosophical anthropology, to be human is to mean. Human being is the production of meaning, where meaning is further understood to come about as the articulation of values. In Capital, Marx's dismissal of "vulgar economists" is based on his argument that they have not perceived the deep structure of social relations among people engaged in production. For Marx, value always shows "a relation between persons as expressed as a relation between things." ${ }^{37}$ It is at the level of social relations that the true meaning of value and exchange must be sought, the level that underlies the surface phenomena of commodities and prices that only formally manifest rclations among people.

The significance of understanding Marxist value in these terms is that doing so illuminates a like undertaking in Bakhtin, who is also trying to come to grips with the categories of value and exchange at a level more essential than their surface manifestation. The general categories dominating Bakhtin's early work-time/ space, self/other, consummated/unconsummated-are the formal means by which specific values get expressed. Dialogue, in Bakhtin's conception of it, is a way to conceive nonidentity; in other words, it is a recognition of the constant need for exchangeand exchange is fueled by differences in value. It is in seeking to work through the complexities of such issues that the utility of perceiving carly Bakhtin through the optic of his later work-and vice versa-makes itself selt. For instance, the centrality of the self/other distinction in these early essays will make some readers uneasy. On the other hand, otherwise sympathetic readers of Marxism and the Philosophy of Language have wondered why Bakhtin/Voloshinov spent so much time land at such a structur- 
ally critical point in the text) on the topic of quotation, the formal means by which we set off our own speech from that of others. Much effort is expended discriminating among Lorch's concept of erlebte Rede, Lerch's uneigentliche direkte Rede, and the more traditional style indirect libre. But in light of Bakhtin's total oeuvre, it seems clear that his lifelong preoccupation with the question "who is talking" is his specific way of intervening in ongoing debates about the subject. How we set off words in the category of direct speech-a term that, after Bakhtin, must always have a certain irony about it-from the category of indirect speech is the defining formal gesture by which we set ourselves off from others.

The movement from Bakhtin's analysis of self/other relations in these early essays to his meditation on the social consequences of speech relations (i.e., quotational and turn-taking strategies) in his later work reveals two more areas of concern he shares with Marx: a quest for the deep structure of work and an attempt to grasp the relation to value of physical labor. In order for this claim to have any meaning, a few words are in order about Bakhtin's dialogically conceived notion of knowledge as a form of quotation and, therefore, of understanding as a form of labor.

Dialogism conceives knowing as the effort of understanding, as "the active reception of speech of the other" laktivnoe vosprijatie chuzhoj rechi," Marxism and the Philosophy of Language, p. 1 I 5; Eng. p. $I I 7 \mid$. The adjective is all-important here: "active reception" means that quoting is never simply mechanical repetition, but constitutes work-it is a labor. A new book by James Lynch, director of the Psychophysiological Laboratory at the University of Maryland's medical school, provides evidence that calling dialogue "work" is not just a metaphor (or not only a metaphor): in a series of imaginative experiments, Lynch has shown a direct corollary between blood pressure levels and the activities of talking and listening. Since 1904, when the modern technique of measuring blood pressure was developed, physicians have insisted their patients not talk while being tested, because talking had the effect of raising "normal" levels. Lynch recognized that "normal" blood pressure in this equation simply meant those levels that were recorded while the patient was "not communicating"; what interested him was transgression of what most doctors considered "normal" effects-the ways in which the act of verbal communication created different effects in the cardiovascular system. 
With the exception of Pavlov, who in his last years posited a relation between the motivated signs of language and the signals of the human body's electrochemical system, Lynch seems to have been the first scientist to recognize that "no other hydraulic or hydrostatic system known to physics [is] influenced by simple conversations." is

That talk should have effects on the working of the body's machinery is a discovery having social implications that go beyond whatever general significance they might have for the mind/body problem: talking alters a "person's relationship to the social environment in a way quite different from when one [is| silent in the same environment.".39 What is significant about this apparent truism is that it indicates the power of speech to effect a bond between entities that are separated in every other way. Homeostasis, as the governor of systems whose totality represents the inner workings of each single organism, would seem to be the most powerful indicator of the degree to which we are all cut off from each other within our somatic monads. When my hand is cut, my body bleeds but yours does not, therefore we say "I" am the subject of the wound. It is not surprising, therefore, that the internal working of the individual body has often been the ground on which traditional ideologies of unique selfhood have been erected.

The discovery that talking has homeostatic effects registered in the individual body has important implications as well for attempts to conceive the speaking subject; the speaker may not "possess" the meaning of his words, but he is at the very least in a relation to those words that is not shared by others who do not at that moment experience the work of their production. Conceiving understanding as a form of quotation implies that meaning is always rented. The physiological effects of the work of talk register where, at any particular moment, energy in the chain of communication is concentrated: one is responsible for the kinetic as well as semantic effect of words.

What is now being suspected by American scientists was long ago taken as an a priori by Russian philosophers. Bakhtin's particular contribution to these developments lies in the degree to which he insists that the physical labor of communication is the particular effort to construct conceptual simultaneities. He goes much further than psychophysiologists in defining the power of language to bridge gaps, for in Marxism and the Philosophy of Language he sees talk as animating simultaneity both within and 
between organisms. Moreover, as opposed to a scientist such as Lynch, Bakhtin assumes talk is within them all the time: there is, in other words, never any "silence," or at least there is none in the sense Lynch intends when he invokes the word. There may be a difference between the cardiovascular response of someone who is talking, in the sense of producing sound waves, and someone who is not talking, in the sense of not producing sound waves. But that difference is one of different degrees of speech participation, not an absolute cutoff between speech and nonspeech. Consciousness is an activity, the deed of actively responding to others' speech both in listening and in talking. The physiological changes recorded by Lynch may be interpreted not as registering an absolute difference between "talkers" and "nontalkers," but rather as registering differences between levels of otherness in language, kinetic distinctions between words of the other requiring less effort from the body and words we seek to mark as our own requiring more effort: "self," in the sense of alter is a project requiring work.

From the perspective of dialogism, the mercury the scientist sees rising in the manometer and the increased speed of the pulse heard through a stethoscope may be said to render palpable the labor not just of talk, but of quotation. Bakhtin insists that quotation is labor, for we cannot transmit another's words, either to another or to ourselves, without in some way working on them. The question "who is talking" with regard to any utterance is also the question "how many are talking?" And since dialogism assumes all words are double-voiced, the answer is always-at least-two: for we call forth, and are ourselves summoned by, the words of others, which we make our own (always in dialogism a relative term/ through borders we build around them. The principles governing structures that we erect to set off "our" words from the words of others constitute the architectonics of answerability.

There is, then, in Bakhtin's aesthetic an emphasis on the primacy of lived experience in all its bewildering specificity. It is an emphasis that accords with the most classical Marxist emphasis on the priority of historical experience vis-à-vis all ideational representations of it, as in the programmatic statement of Marx and Engels themselves in The German Ideology: "The production of notions, ideas, and consciousness is from the beginning directly interwoven with the material activity and material intercourse of human beings, the language of real life." 
If there is to be any productive cross-fertilization between Bakhtin and Marx, it would now seem to have to assume the form of inscribing a Marxist emphasis on politics, economics, and social theory into dialogism's obsession with the personhood of individuals and the metalinguistics in which utterance is a deed. With these essays, at least the tools for such a labor become available.

\section{VI}

In the last five years of his life, Bakhtin began to fill his notebooks with sketches for articles on the question of author and hero, self and other, and the relation of art to life. He returned, in other words, to the same subjects that had engaged him in these fragments from his youth. But in Bakhtin's conception of things, there can be no repetition as such: texts, insofar as they are not natural signs, such as fingerprints, are utterances and therefore links in the great chain of speech communication. Their appropriation by another is a new event.

I shall not conclude by attempting to suggest what the entrance of these texts into current discussion might portend, for such an "analysis usually fusses about in the narrow space of small time, that is, in the space of the present day and the recent past and the imaginable-desired or frightening-future . . . there is no understanding of evaluative nonpredetermination, unexpectedness, as it were, 'surprisingness,' absolute innovation, miracle ..."41 What can be said is that the texts in this new anthology constitute a particularly significant event, because with them we have for the first time something like a complete Bakhtin, a whole utterance, as it were. Readers may now enter into dialogue with Bakhtin (even to dispute him) at the higher level of a second consciousness, that is, with "the consciousness of the person who understands and responds: herein lies a potential infinity of responses, languages, codes. Infinity against infinity." ${ }^{42}$

\section{Notes}

I. The story is unfortunately apocryphal. It was current during Lewis Carroll's lifetime, driving the author in a note appended to the preface of his Symbolic Logic (1896) to deny "such an absolute fiction." See Roger 
Lancelyn Green's revision of The Lewis Carroll Handbook, by Sidney Herbert Williams and Falconer Madan; further revised by Denis Crutch (Folkestone, England: Dawson, 1979). p. I 82.

2. All have been published by the University of Texas Press, Austin and London. The first was The Dialogic Imagination: Four Essays by M. M. Bakhtin, ed. Michael Holquist, trans. Caryl Emerson and Michael Holquist, I98I. The second was Speech Genres and Other Late Essays, ed. Caryl Emerson and Michael Holquist, trans. Vern McGee, 1987.

3. One indication of the school's current obscurity is that relatively little attention is paid to it: there is really no good synthetic or historical account covering the different subgroups of Neo-Kantians, so anyone interested in pursuing relations between them and Bakhtin is compelled to go through the (mostly untranslated) works of such thinkers as Hermann Cohen or Paul Natorp.

4. See Katerina Clark and Michael Holquist, "The Influence of Kant in the Early Work of M.M. Bakhtin," Literary Theory and Criticism (Festschrift for René Wellek), ed. Joseph P. Strelka (Bern: Peter Lang, 1984), pp. 299-31 3.

5. Paul Natorp and Ernst Cassirer are the other leading members of the school, although it could be argued that Cassirer's work after the twenties sets him apart in significant ways from basic "Marburgian" tenets. But he never abandoned the Marburgian obsession with the precise sciences of physics and mathematics.

6. V. I. Lenin, Materializm i empirokritisizm, in Polnoe sobranie sochinenij (Moscow: Nauka, 1947), vol. 18, pp. 326-327.

7. Cf. his Logik der reinen Erkenntnis (Berlin: B. Cassirer, 1902).

8. Voprosy literatury, no. $6(1977), 307-308$. It was reprinted in subsequent anthologies of Bakhtin's works in 1979 and 1986.

9. In the 1975 anthology of Bakhtin's works, Voprosy literatury $i$ estetiki (Moscow: Khudozhestvennaja literatura, 1975), pp. 6-71. Also included in the 1986 anthology, Literaturno-kriticheskie stat' $i$ (Moscow: Khudozhestvennaja literatura, I986), pp. 26-89.

Io. In Filosofiia i sociologija nauki i texniki: Ezhegodnik, 1984-1985, pp. $80-138$.

I I. In Estetiki slovesnogo tvorchestva.

12. Given Bakhtin's passionate insistence on particularity, an "-ism" invoked to name his own achievement must have a certain awkwardness about it. Nevertheless, now that we have something approaching a Bakhtinian canon or oeuvre, it would seem useful to have a comprehensive term to name the principles that hold together Bakhtin's heterogeneous studies. Given the importance dialogue has in Bakhtin's thought, it is not surprising that "dialogism" is emerging as the term most likely to provide the needed synthesis.

13. Nevertheless, when Vadim Kozhinov went back to Mordovia in 1972 in order to reclaim the manuscripts, he was horrified to find them 
moldering away among the rats in a Saransk lumber room. Several pages of these unfinished fragments, according to Bakhtin's own pagination, were missing, compounding the difficulty of "consummating" them as texts. A small group of devoted young people worked for a long time to decipher the notebooks and prepare typed manuscripts from them: anyone interested in Bakhtin owes a great debt to S. M. Aleksandrov, G. S. Bernstein, and, above all, L. V. Deryugina.

I 4. M. M. Bakhtin, Literaturno-kriticheskie stat'i, ed. S. G. Bocharov, V. V. Kozhinov (Moscow: Khudozhestvennaja literatura, I986), p. 53 I.

is. M. M. Bakhtin, "K filosofii postupka," p. 122.

16. "The Problem of Speech Genres," in Speech Genres and Other Late Essays, p. 201.

17. M. M. Bakhtin, "K filosofii postupka," p. 86.

18. "Forms of Time and the Chronotape in the Novel," in The Dialogic Imagination. p. 85 .

19. Bakhtin's reservations about Structuralism, with its emphasis on mechanical constructs, are apparent in two later essays, "The Problem of the Text in Linguistics, Philosophy, and Other Human Sciences," and "Answer to a Question from the Editors of Novyi Mir," both translated in Speech Genres and Other Late Essays.

20. James Fernandez, "Exploded Worlds-Text as a Metaphor for Ethnography (and Vice Versa)," Dialectical Anthropology 10 (1985), 23.

21. Paul Ricocur, "The Model of the Text: Meaningful Action Considcred as a Text," Social Research II/2 (1971), 529-562; and "Metaphor and the Main Problem of Hermeneutics," New Literary History, 6/1 (1974), 95-110.

22. For the latest (but certainly not the last) exchange in this debate, which-while I myself still accept Bakhtin's major role-is probably ultimately unanswerable in any form that will definitively meet the objections of both sides, see the forum in Slavic and East European lournal 30/I (Spring 1986): 96-102. References to other articles devoted to the debate are also to be found in the forum.

23. For more extended treatment of Bakhtin's relation to Neo-Kantianism, see Clark and Holquist, "The Influence of Kant in the Early Work of M. M. Bakhtin," pp. 299-313.

24. Henri Bergson, Matter and Memory, trans. Nancy Margaret Paul and W. Scott Palmer (London: George Allen and Unwin, I 9 i I), p. 6.

25. For a more claborate account of Bakhtin's relation to Bergson as Bakhtin hımself conceived it, see the articles on Vitalism he wrote under the name of his friend Ivan Kanaev: I. I. Kanaev, "Sovremennyi vitalizm," Chelovek i priroda (1926), I: 33-42; II: 9-23.

26. Especially in those parts of the Cartesian Meditations where Husserl concerns himself with the danger of his phenomenological subject devolving into solipsism, leading him to meditate on the otherness of others. Cl. Husserl's insistence on the "original pairing" of ego and alter 
ego (Edmund Husserl, Cartesian Meditations: An Introduction to Phenomenology, trans. Dorion Cairns [The Hague: Martinus Niihoff, 1960], pp. $91-113$, esp. p. I I2, and those parts of the Meditations where he concentrates on the different experience of being embodied in me and in the other, esp. pp. I I7- I23).

27. Scheler's work on sympathy is the relevant text here. See Max Scheler, The Nature of Sympathy, trans. Peter Heath (Hamden, Conn.: Archon, 1970).

28. Merleau-Ponty is especially concerned with thinking through the role of physical bodies in self/other distinctions. See Maurice MerleauPonty, Phenomenology of Perception, trans. Colin Smith (London: Routledge and Kegan Paul, 1962).

29. Especially in his classic essay on "the mirror stage." See: "The Mirror-Stage as Formative of the Function of the I," in Ecrits: A Selection, trans. Alan Sheridan (New York: Norton, 1977), pp. I-7. See also the Neal H. Bruss essay on Bakhtin and Lacan, which appeared as an appendix in the first edition of the Bakhtin/Voloshinov book on Freud: V. N. Voloshinov, Freudianism: A Marxist Critique, trans. I. R. Titunik (New York: Academic Press, 1973).

30. See Katerina Clark and Michael Holquist, Mikhail Bakhtin (Cambridge, Mass.: Harvard University Press, 1984), pp. 23, 79-8 I. A more extensive treatment has been provided by Nina Perlina: "Bakhtin and Buber: The Concept of Dialogic Discourse," Studies in Twentieth Century Literature 9 (1984): $13-28$.

31. See especially Cohen's essays on the distinctiveness of the Hebrew concept of deity in Reason and Hope: Hermann Cohen's lewish Writings, trans. Ewa Jospe (New York: Norton, 1971).

32. Martin Heidegger, Being and Time, trans. John Macquarrie and Edward Robinson (New York: Harper and Row, 1962), p. I6I.

33. Jean-Paul Sartre., Being and Nothingness: An Essay on Phenomenological Ontology, trans. Hazel Barnes (New York: Philosophical Library, 19561, pp. 303-359.

34. See especially another work of Sartre's, Transcendence of the Ego: An Existentialist Theory of the Ego, trans. Forrest Williams and Robert Kirkpatrick (New York: Farrar, Straus, and Giroux [Noonday Press], 1957). But the emphasis on transcendence of the ego indicates precisely where Bakhtin would diverge from Sartre in conceiving the self.

35. See Jean-Paul Sartre, Critique of Dialectical Reason, trans. Alan Sheridan-Smith (London: New Left Books, 1976 ).

36. In some of my previous attempts to come to grips with the question of Bakhtin's relation to Marx, I now believe I oversimplified matters to an unjustifiable degree. There can be little doubt that certain phrases associated with Bolshevik jargon of the time, which occur even in texts signed by Bakhtin himself, were indeed introduced for purposes of protective coloration. An example of this would be his use of the highly 
marked phrase "kulak-bloodsucker" (kulak-miroed) in an essay of 1929 ("Predislovie," in L. Tolstoy, Polnoe sobranie khudozhestvennykh proizvedenil, ed. K. Khalabaev and B. Eikhenbaum (Moscow: Gosizdat, I 929|l, vol. I I, p. viii.). But such historicist details should not obscure Bakhtin's more fundamental relation to Marxist thought independent of Bolshevik practice, especially in light of these early essays, as 1 try to suggest here.

37. Karl Marx, Capital (Chicago: Charles H. Kerr, I9 I9), vol. I, p. 85 n.

38. James J. Lynch, The Language of the Heart: The Body's Response to Human Dialogue (New York: Basic Books, I985), p. 49.

39. Ibid., p. 178 .

40. Karl Marx and Frederick Engels, The German Ideology (Moscow: Progress P'ublishers, 19761, p. 42.

4I. "Toward a Methodology of the Human Sciences," Speech Genres, p. 167

42. "From Notes Made in 1970-1971," in Speech Genres, p. 136. 
This page intentionally left blank 
Art and Answerability 
This page intentionally left blank 